DOI https://doi.org/10.36059/978-966-397-208-4/1-20

\title{
PSYCHOLOGICAL COMMUNICATION PECULIARITIES IN THE DEVELOPMENT OF PRESCHOOL CHILDREN
}

\section{Guba N. O.}

\section{INTRODUCTION}

New economic conditions and social-psychological processes that are taking place now in Ukraine increase the importance of searching for more efficient ways of improving personality education system. The urgency of effective solving the problems related to personal-oriented communication in the context of family interaction is increasing every year.

With the development of a personality-centered approach the number of issues related to the field of communication has significantly increased recently. This is due to the fact, that the formation of self-awareness (as the most important factor of individuality and activity of an individual) is impossible without interpersonal communication.

At preschool age intensive development of mental functions of the child happen: they learn the surrounding social reality in its interconnection and manifestations and they form as a person. Intensive accommodation of the generations' experience happens through the interaction of the preschooler with the surrounding adults, especially parents. That is why the family as the closest human environment is an important and practically indispensable chain of the social formation system of the individual. Positive emotional inviroment in the family, harmonious relationships between parents and the child as much as personal-oriented communication style contribute to the development of emotions and social feelings of the children, their assimilation of spiritual and moral values. It also helps children to understand better the parent's institutions and requirements. However conflicts and tensions between parents and children lead to disturbances in the emotional, volitional development of children, difficulties in social adaptation, deviations in behavior, etc.

\section{Psychological analysis of communication of a child in preschool age}

Preschool age is a period when children learn all kinds of information. According to the concept of L.S. Vygotsky the development of the child occurs in the form of learning about social and historical experience of humanity. 
O.M. Leont'ev described the process of mental development of the child. He wrote: "It is a process that results in the reproduction by the individual of historically human properties, abilities and behaviors that have formed"1.

At the heart of the mental development of children is their specific reproductive activity, through which the child assimilates the historically fundamental needs and abilities of the people who have been formed for inclusion in active work and social life. Such learning requires the communication of the child with adults who have already (in one way or another) mastered the culture and are able to pass on the accumulated experience to them, to teach them the ways of practical and mental activity used by human beings.

At various stages of mental development the child with the help of adults actively adopts the need for communication, since communication is a prerequisite for human existence and at the same time one of the main factors and the most important source of its mental development in ontogeny. Communication is "historically the first form of human culture development it is from the assimilation of the need for it that an individual begins his or her own development"2.

The formation of the child's psyche, their personality and their consciousness take place in a process of communication. After all, "communication plays a crucial role not only in enriching the content of the child's consciousness and in acquiring the child with new knowledge and skills; it also determines the structure of consciousness, the indirect structure of higher, specifically human mental processes".

The development of a child within the framework of the theory of cultural and historical development is understood by L.S. Vygotsky as a process of assigning to children the social and historical experience gained by previous generations. Gaining this experience is possible when children communicate with adults. Communication plays a crucial role not only in the enrichment of the content of the child's consciousness but also determines its structure.

If we summarize the impact of communication on the overall mental development of the child we can say that:

- it accelerates the development of children (the emergence and further development of both operational, technical and perceptual skills);

- it allows to overcome the stressful situations;

- it also allows to correct defects which have appeared at children at the wrong upbringing.

1 Вопросы психологии ребенка дошкольного возраста: Сборник статей / под ред. А.Н. Леонтьева. Москва, 1995. 144 с.

2 Выготский Л.С. Собрание сочинений: в 6-ти томах. Педагогіка. Т. 2: Москва: Психология, 1984. 397 с. 
This influence can be traced in many areas of mental development: from the area of curiosity of children to the development of personality. It happens due to the fact that:

- for young children the adult is a rich source of various actions (sensorimotor, auditory, tactile, etc.);

- when enriching the experience of the child, the adult first acquaints him with something and then often puts the task in front of him to master some new skill;

- the adult supports the efforts of the child, helps to do corrections;

- a child in contact with adults watches their activities and draws samples for imitation.

M.I. Lysina identifies several types of communication through which children interact with adults:

- expressive-mimic: appears firstly in the ontogeny (during the first two months of life) and serve as a manifestation of the emotional states of the child and their ability to address gestures to others; they also express the content of communication that cannot be conveyed with the necessary precision through other means - attention, interest, etc.

- visual and effective: they arise later (up to 3 years) and also have a sign function without which no mutual understanding between people is possible; it differs from expressive-mimetic with greater arbitrariness;

- language operations: allow to go beyond the private situation and establish wider interaction ${ }^{3}$.

According to M.I. Lysina, in the first seven years of life not only the quantitative enrichment of communication of the child with others happen, but also there are qualitative transformations of communication activities related to changes in its content, means and results. There are many works of different authors: domestic (O.M. Leont'ev, F.I. Fradkin, R.L. RozengartPupko, N.M. Shchelovanov and N.M. Aksarina, D.B. Elkonin, N.L. Figurin and M.P. Denisov, R.E. Zhukovskaya and others) and foreign (McCarthy, X. Gevirtz, R.Washborn, I. Brekbill, etc.) which contain materials that describe the peculiarities of some forms of communication between the child and adults.

M.I. Lysina described those qualitatively-specific forms in which communicative activity of children in early and preschool childhood is carried out.

From the point of view of M.I. Lysina the changes of certain aspects that characterize the development of various structural components of

3 Лисина М.И., Силвестру А.И. Психология самопознания у дошкольников. Кишинев: «Штинца», 1983. 63 с. 
communication (needs, motives, operations, etc.) give rise to integral, holistic entities that are the levels of development of communicative activity. These qualitatively specific formations which are the stages of the ontogeny of communication have been called "forms of communication".

Thus the form of communication is communicative activity at a certain stage of its development, taken in a complete set of features and characterized by several parameters. Among these are the 5 following parameters:

1. Time of the occurrence of this form of communication during preschool childhood;

2. The place it occupies in the wider life of the child;

3. The main content of the needs that are met by children in this form of communication;

4. Leading motives that encourage the child at a certain stage of development to communicate with others;

5. The main means of communication through which the child communicates with other people.

The appearance of communication of this form in ontogeny is conditional since the formation of the form of communication is a long process and the specific terms of its completion vary greatly in different children.

The motives for communication are divided into three categories depending on what the communicative actions of the child are aimed at. These are: a) business motives or aspirations for practical cooperation with an adult in a given specific situation, b) cognitive motives or communication about events and phenomena that go beyond the specific situation of a child's interaction with an adult c) personal motives or communication on the grounds affecting the child and the adult reffering to a particular interaction situation or regardless of it.

Communication Content is the information exchanged between a child and an adult during the communication process. In this case it is possible to distinguish a more general interaction as the background on which the child expresses his relation to another person. The emergence of an image of another person (the idea of him) is the purpose and result of communication, as determined by the need for communication. The nature of this image depends directly on the content of the communication and is ultimately determined by the more general interaction of the child and the adult against which their communication unfolds.

Means of communication are those operations by which the child addresses an adult and receives information from them about the adult's relationship to him.

In the first half of preschool childhood, a non-situational-cognitive form of communication can be observed in the child. It is indirect and it is not 
involved in practical cooperation with adults but in joint cognitive activity we can say in "theoretical" cooperation. Visual manipulations of young children were also largely aimed at revealing the properties of objects. The child's practical "trial and error" is the basis upon which his or her orientative and perceptual actions are then formed ${ }^{4}$. But the primitiveness of the early manipulations and the elementary forms of cooperation with adults allow children to establish only the most superficial, insignificant properties of things. However the development of curiosity and the constant improvement of ways to satisfy it (perception, visual-effective, and later visual-based thinking on mastering the language) force the child to ask more and more difficult questions. It is shown that the preschooler tries to understand as little as the origin and the device of peace, the interconnections in nature, the secret essence of things...

But the ability to understand such problems on their own in a young child is very limited. The only real way to understand is for them to communicate with others around them. The children who love the word "why" bring an avalanche of questions to the adults. Naturally the leader in this form of communication is a cognitive motive. An adult acts in front of children in a new capacity - as an erudite who is able to dispel their doubts, give them the information they need, provide the necessary information. And since "theoretical cooperation" discusses issues far from the interaction between children and the adults communication gains - for the first time after the birth of a child - an extra-situational character.

When considering the content of communicative needs in children with non-situational-cognitive form of communication one common border of young and especially middle-aged children is distinguished - their increased offensiveness. Z.M. Boguslavskaya, O.O. Smirnova report that words of encouragement cause unprecedented delight in preschoolers: children jump, clap their hands, make victorious cries, they are even capable of kissing a little-known person. And the mildest reproach can be perceived with extreme exaggeration: children argue, angry, some cry, others immediately leave the room and the next time they try to meet, they refuse to contact ${ }^{5}$.

This heightened sensitivity of children to the attitude of adults is not accidental: it seems to reflect some important transformations in the need for communication with children. All this leads to the conclusion that the extrasituational and cognitive form of communication is characterized by the child's desire for respect for the adult. Children want praise and do not want to accept comments, they take it as a personal resentment.

4 Психология личности и деятельности дошкольника / под ред. А.В. Запорожца, Д.Б. Эльконина. Москва: Просвещение, 1965.98 с.

5 Актуальне проблемы воспитания и обучения дошкольников. Сборник научных трудов. Москва, Педагогика, 1985. 403 с. 
Children's need for respect can be the basis for serious violations of the child's behavior and activity: they begin to resist, become tearful, avoid contact. But this is not necessarily completely eliminated. Z.M. Boguslavskaya tested various techniques in her relationships with children and proved that a mild joke of an adult and a caring attitude towards a child who did a mistake and most importantly - a constant demonstration of their confidence in his abilities, talents and good will unleash their initiative and renew their commitment to working with adults ${ }^{6}$.

The essential tool of communication for children with non-situationalcognitive (as well as non-situational-personal) form is, of course, language operations: they alone allow children to go beyond the limited situation into a boundless surrounding world. Interestingly preschoolers not only use the word but also turn it into a special object of study. Children have a craving for word formation, a play with the word, which helps them master their mother tongue.

Also the features of the form of communication are linked with the leading activities of the relevant age period. At preschool age the game is one of the most important aspect among all activities of the child. Special studies have shown that in the early stages of the development of play children try to reflect (in the course of it) a largely external, "real" aspect of adult activity that they develop through play. Therefore they attach great importance to the use of various substitutes symbolizing "adult" equipment, professional attire and characteristic attributes. Finding appropriate "substitutes" allows the child to better understand the functions and meanings of the various products of human culture and also nourishes their greedy curiosity. So cognitive communication is closely intertwined with the play of children.

By the end of preschool age children recieve a higher form of communication with adults - non-situational personal. The personal motive of communication - the leading factor in this form of communicative activity has a completely different character. The adult performs in front of the children in the fullest of their gifts, characteristics and life experience. He or she is now not just an individual or an abstract personality for a preschooler but also a specific historical and social personality and a member of society. The child reflects not only the side to which the adult is directly returned to them in this situation where the adult treats them, feeds them, teaches them the adult receives their own independent existence in the eyes of the child. For the preschoolers such details from the life of an adult which do not touch them

\footnotetext{
${ }^{6}$ Общение детей в детском саду и семье / под ред. Т.А. Репина, Р.Б. Стеркина и др. Москва: Педагогика, 1990. 150 с.
} 
in any way but allow to reproduce in the completeness of concrete details a complete image of this person.

The internal transformation of the personal motives of communication in children in the transition from childhood to preschool age, filling them with completely new material indicate that the communicative need which they have identified, has now acquired a new meaning. Indeed senior preschoolers are characterized by a desire not just for the kind attention of adults but also for understanding and empathy with them. The new content of the communicative need is expressed in the fact that the child does not now necessarily insist on praise: much more important for them to know how it should be. And although they are upset if they have acted wrongly, they willingly agree to amend their work, change their mind or attitude to the issues discussed, in order to reach a community of views and evaluations with the adult. The coincidence of their position with the position of the adults serves as a proof of the child's correctness. The child is now in no hurry to argue with the adult - they are sensitive to their wave and tries at first a little better to understand the adults, to find a reason why they think so but not otherwise.

Striving for a community of views with the adults give children reliance of thinking about ethical concepts or when forming moral thoughts because the rules of behavior in society and relationships with social partners by their very origin is social, and only the adults who have mastered social experience can help the child determine the right path. It was established (by A.R. Ruzskaya, L.N. Abramova) that so many complaints of children against their kindergarten friends were caused by a desire to check themselves whether they had mastered how to do something. Complaining, preschoolers often do not want punishment for another child - they are just waiting for their adult to judge. Therefore non-situational-personal communication increases the susceptibility of children to educational activities and facilitates the rapid learning of adult's exhortations ${ }^{7}$.

The new form of communication is closely linked to the higher levels of game development for preschool children. The child now pays less attention to the material side of the reality they have reproduced - now she of he is mainly interested in those complex relationships that develop between people in the family and at work. In communication with adults the child draws material for their games and keenly observes all shades of older behavior when they collide with each other. Contact with adults and with older children opens up the prospect of their future life for the coming years: they realize that they will soon study at school.

\footnotetext{
${ }^{7}$ Психология семьи. Сборник статей. Москва: Вопросы психологии, 2002. С. 5-11.
} 
Thus the acquisition of new information by children improves with age but within each age group the worst results have children with situational-business form of communication and the best - children who use extra-personal form. Children with extra-cognitive form of communicative activity occupy an intermediate position. The experiments of O.O. Smirnova as well as Z.M. Boguslavskaya, D.B. Godovikova and X.T. Bedelbayeva allowed to establish that special formation of non-situational and personal communication in preschool children was accompanied by increasing their attention to the actions of adults, their organization and purposeful behavior. In parallel the efficiency of assimilation of information was increased by 1.5-2 times.

Non-situational-personal communication is the highest form of communication activity observed in children younger than 7 years. Its role in the life of a child is to master the rules of behavior in the social world and to understand some of its laws and relationships.

Thus, the parameters of communication of a child at preschool age can be described as following:

1. Form of communication:

1) extra-cognitive (up to $4-5$ years);

2) extra-personal (5-6 years).

2. Content of the need for communication:

1) the need for attention, cooperation and respect (4-5 years);

2) the need for goodwill, cooperation, respect for the adult in the lead role of the desire for empathy and understanding (5-6 years).

3. The leading motive of communication:

1) cognitive: adult as an erudite and a source of knowledge about nonsituational objects, a partner for discussion of causes and relationships; (4-5 years);

2) personal: an adult as a holistic personality with knowledge, skills and norms (5-6 years).

4. The importance of this form of communication in the overall development of the child:

1) primary penetration of the external sensual essence of phenomena and the development of visual forms of thinking;

2) involvement in the moral and ethical values of society, the transition to discursive thinking (5-6 years $)^{8}$.

Famous researchers of the family M.I. Lisina, A.S. Spivakovskaya, V.N. Druzhinin and others have repeatedly highlighted the impact of relationships in the family on the child's mental development: when "appropriate conditions of family upbringing can form personal traits that

\footnotetext{
${ }^{8}$ Лисина М.И. Воспитание детей раннего возраста в семье. Киев: Знание, 1983. 48 с.
} 
hinder or, conversely, promote the manifestation of general and special abilities in training or professional activity"".

\section{Family as the main psychological factor in communication in the development of a preschool child}

A family, which lays the foundations for all the moral qualities of a person and forms the first spiritual needs plays a big role in shaping a new human being. The emotional contacts of the child with the parents play an extremely important role in the formation of the spiritual needs of the person and the desire of the older generation to convey to their children their moral values and to embody their moral ideal in their spiritual face.

The emotional potential of the family conceals great potential for educational influence on the child. In combination with the ideological guidance of parents, emotional factors are the main prerequisite for the development of the moral dignity of the child. On the basis of the positive evaluative attitude of the parents, the emotional-value attitude of the child towards himself is formed and also their need for respect of others.

The affective saturation of communication between family members and the predominance of positive and negative emotions significantly affects the child's well-being and his or her worldview and awareness of the image of close adults. It is one of the features that mark the most typical range of experiences of family members, their moods, affections, emotional contacts, displays of love and respect for each other and it forms the psychological climate of the family as a micro-collective.

The psychological climate of the family is one of the most powerful factors in the emotional impact on the child. From the atmosphere in the family the moral character of the parents largely depends on the orientation of the child's activity, his or her positive or negative state of health, the nature of the adolescent's personal expectations about others.

The negative relationships between parents affects on child's well-being dramatically. Under these conditions children experience so-called conflict experiences. The latter are the result of a collision in the mind of the child opposite in their emotional coloring of the relationship to a loved one.

Emotional factors are important not only because they exacerbate or diminish educational effects. In a certain emotional attitude of an adult to objects or phenomena, attitude to the meaning of existence, objects and phenomena, their value - everything is embedded in the child. What adults praise, protect, why they spend their energy, what they admire, why they suffer, and so on, gradually becomes the subject of the child's experiences.

\footnotetext{
${ }^{9}$ Дружинин В.О. Психология семьи. Москва: КСП., 1996. 368 с.
} 
And this means that the true meaning of things exists for them so to speak at the pre-judicial level. Hence the conclusion that the social "value" of their "I" will depend on what the child will experience in the first years of their life what will be the orientation of their feelings.

Emotionally children experience not only adult talk but also their entire behavior. That this is a very important factor influencing the child is confirmed by the nature of children's games in which they play the thing that most strikes them. Extremely deep psychological observations of pre-school children can be found in the works of K.D. Ushinsky. It not only reveals the content of the play activity but also shows its importance for the moral development of the child.

The mentioned factors of emotional influence of a family on a child psychological climate, behavior and conversations of parents, their relationships and various manifestations of the appraisal attitude of close adults to the child - all of these factors, first of all, influence on the formation of their own self-esteem, decrease or increase of the level of emotional value, form attitude towards themselves.

Emotional potential of the educational influence of the family can be effectively used only with knowledge of the psychological mechanisms of action of these factors ${ }^{10}$.

The authority of parents contains an emotional charge which is not yet fully explored. The authority of a close adult is based on the child's belief in the undoubted dignity and superiority of the eldest, endowed with power, wisdom and knowledge. However why does not this belief always arise? Not all adults have real authority in a child (even preschoolers). The basis of this belief is the close emotional contact of the child with the adult through which he or she feels love, care, attention and afflictions of their closest and sweetest person. Such emotional contacts do not occur by the magic wand and it doesn't happen suddenly especially when parents who gave up to bring up their grandmother's baby thought to caress her during the month. We must mention that children in their own way do not forgive their parents lighthearted attitude to themselves: they just do not believe them. Even if their mind tells a child that in this case the adults are right (but in the absence of authority there is no enthusiastic and unconditional attitude to everything that parents say and do) it is not perceived by children as wise and true. If there is no close emotional contact with the parents the child also has no desire to earn their approval, that is, to be the one they would like to see.

The influence of parental authority which is for the child a guarantee of the infallibility of the thoughts, actions and views of the adult, is close in

${ }^{10}$ Титаренко В.Я. Семья и формирование личности. Москва: Мысль, 1987. 342 с. 
mechanism of its action to suggestion. Information that children receive from a reputable adult is perceived by them as personally meaningful, encouraging and non-intrusive.

The power of the family's educational influence is also that parents can shape the child's spiritual needs from the first years of life. Formation of needs is again due to the influence on the emotional sphere of the child. Thus the positive emotional attitude of the parents towards the child and the approval and encouragement of their own activity in the process of which certain tendencies and abilities are revealed inevitably leads to an increase in the level of the emotional-value attitude of the child towards themselves. Maintaining self-esteem at the level that has been shaped in this way by the influence of the family becomes one of the leading social needs of the child. In the case of environmental influences that can lead to a decrease of the child's self-esteem they exprience a lot of negative emotions.

Thus the emotional susceptibility of preschool children to educational influences places particular responsibility on close adults.

R.L. Selman studied the process of developing parents' ideas about children's development. According to R.L. Selman four degrees have a place in everyone's life. He also suggested stages of development of views on childparent relations ${ }^{11}$.

At stage " 0 " the relationship between parents and children is described in the categories "master-servant". They arise in understanding the physical dependence of the child on the adult. The child, not having the opportunity to independently meet their living needs, is forced to take a position of submission and obedience to the whole range of relationships that can only exist between the child and the adult.

In Stage " 1 " the relationship between children and parents is addressed in the "worried-helper" system. The child's need for parents is explained by the fact that it needs protection from danger and financial support. Parents who love a child provide this help. Children express their feelings through obedience.

At Stage "2" the relationship is described as a "curator (adviser) - needs responder". In this case the parents' position is to give the child possible guidance (not to impose his own opinion) because the children need psychological and emotional support. Parents should be sensitive to the child's psychological needs.

At Stage "3" relationships are presented as "tolerance - respect". In this case, the position of parents is distinguished not only by the fact that they

11 Эмоциональное развитие дошкольника / под ред. А.Д. Кошелевой. Москва: Просвещение, 1985.368 с. 
observe the development of their children but they actively form in them a sense of self-respect and psychological maturity. In this case ideal parents are tolerant and ideal children are receptive to their parents' psychological needs.

Stage "4" is indicated by R.L. Selman as a Relationship to a "changing lifestyle system". Autonomy and independence distinguish this system of relationships, however, they may undergo some fluctuations over the course of their lives.

From the perspective of R.L. Selman these stages are nothing but the stages that pass in the development of people's perceptions of parent-child relationships.

S.M. Newberg continued the line of research begun by R.L. Selman studying parents' perceptions of their relationships with their children. As a result several steps were found in parental orientations. One of them is "selfish orientation". For parents, the child acts as an object of action for which they project their desires and needs.

"Conditional orientation" involves the perception of the child through the prism of traditions and attitudes adopted in certain society. The role of the parents in this case is reduced to performing socially outlined actions.

"Subjective-individualistic orientation" allows you to consider your child as something unique. The adult solidifies with the needs of the child.

"Interactive orientation" is that the parent perceives the child as a complex and changing system. Like the child, parents grow in their role: they not only meet the needs of the child but also try to find ways to balance its needs with their own so that each of them meets with understanding.

From the view of S.M. Newberg there is every reason to believe that these types of orientation - the degree of development of parents' views on their relationship with children.

Four stages of development of parental views are distinguished by A.L. Samerov and L.A. Fale. They made an attempt to formulate stages in the parents' understanding of their child similar to the stages of the development of intelligence, highlighted by J. Piaget (sensorimotor, pre-operative, concrete operations and formal-logical). According to this approach the first stage is designated as "symbiotic level": parents do not see themselves as something separate from the child; the child's behavior is explained directly, related to their current activity.

The second stage is the "categorical level": parents perceive themselves and children as separate elements: the behavior of children is considered in the logic of the child's development and not merely as a result of the activity of the adult. Child development has an organic and environmentally dependent determinant. At this stage parents tend to "label their own child" (kind, beautiful, smart, etc.). 
Stage three is the "compensation level". At this stage parents are able to see their child as one who has an independent position not only from the parents' actions but also from the "labels" that the adult attributes to him. It comes to the realization that features of a child's behavior may depend on age. For example babies are known to cry; children who start walking are inactive; teens have a gloomy mood. Development is understood as the result of the interaction of organic characteristics of children and the environment.

In the fourth stage called the "promising level" parents are able to see the child's behavior as a result of his or her individual experience of interacting with the environment. These or other abnormalities in the development of the child are explained more by deviations in the child's relationship with the environment than by organic characteristics.

L.M. Jonsons, L.M. Gerris tried to analyze the impact of family social status on parental attitudes, views and behavior. The interaction of parents with children was analyzed in four categories: "use of force" - threat or punishment of physical or non-physical punishment; "Induction" - an explanation of the consequences of a breach of rules and an explanation of how to apologize, suggestions of alternative behavior; "Responsibility" - a plea for explaining one's behavior, comforting the child and punishing the one who provoked the violation; "Rejection" is the explicit rejection of a child's behavior with or without force ${ }^{12}$.

It is well known that child-parent relationships are different from all other types of interpersonal relationships. Revealing their specifics O.O. Smirnova points out that they are "characterized by strong emotional significance" for both the child and the parents. And in the "parent-child" system ambivalence is always present in which in one case the parents have to save the child from danger, and in the other, to allow them to gain independent experience in interaction with the environment. There is another peculiarity in the attitude of parents towards their child and it depends on the change of age ${ }^{13}$.

In O.O. Smirnova's opinion the parental attitude towards the child can be represented as a scheme (see figure 1 ).

The concept of "parental relationship" has the most general character pointing to the mutual connection, belonging, dependence between the parent and the child. Parental attitude includes a subjective-evaluative, consciouslyselective idea of the child which determines the peculiarities of the child's perception and the way to communicate with it, the nature of the methods of

12 Творча спадщина Г.С. Костюка та сучасна психологія. До 100-річчя від дня народження академіка Г.С. Костюка. Матеріалли III з'їзду Товариства психологів України. Київ, 2000. 311 с.

${ }^{13}$ Смирнова Е.О. Психология ребенка. Москва: Знание, 1997. 326 с. 
action. As a rule emotional, cognitive and behavioral components are distinguished in the structure of parental attitude. The terms "parental position" and "parental establishment" are used practically as synonyms for the concept of "parental attitude" sometimes different in the level of awareness. The parental position is more likely to be associated with consciously accepted, produced views, intentions; the installation is less conscious.

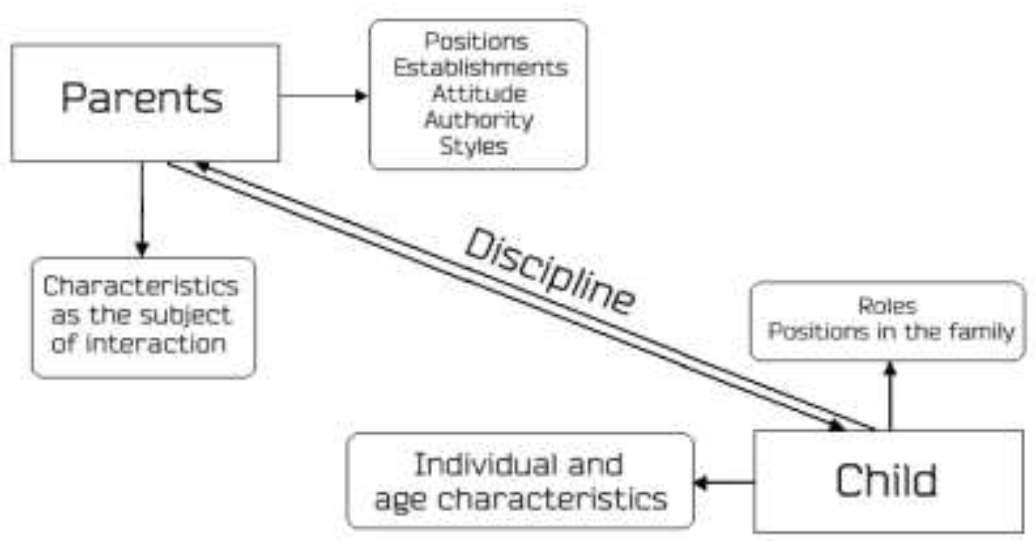

Fig. 1. Parental attitude towards the child

Various options of parental positions, attitudes, parental (often maternal) attitude are described:

1. Symbiosis, authoritarianism, emotional rejection ("little failure").

2. Support, authorization; adaptation to the needs of the child; attitude with a formal sense of obligation in the absence of genuine interest in the child; inconsistent behavior.

3. Cooperation, isolation, rivalry, pseudo-cooperation.

4. Favorable - the authority of love, kindness, respect. Negative - the authority of suppression, distance, pedantry, resonance, bribery (A.S. Makarenko).

5. Template positions all crippling family including child-parent relationships: a preventative "peacemaker"; The "accuser"; a prudent "computer"; bewildered "distractor". Positive behavior is flexible or balanced where different techniques are used not deliberately but consciously taking into account the consequences of their actions ${ }^{14}$.

\footnotetext{
${ }^{14}$ Психология семьи. / Сборник статей. Москва: Вопросы психологии, 2002. С. 5-11.
} 
Violations of the family environment and the family atmosphere can be classified in terms of satisfaction of the most important (according to Z. Mateychek) human needs: the need for active contact with the environment and the need for active control of external reality. The environment in extreme cases can be excessively persistent or too volatile with changing people and circumstances; the control parameters vary from isolation to dependency.

1. The ultra-stable, emotionally indifferent environment results in social hypoactivity: passivity, lack of interest, autism, delay in language and mental development.

2. The changing emotionally indifferent environment leads to hyperactivity in general: to anxiety, lack of focus, uneven mental development with delay.

3. The ultra-stable environment combined with emotional dependence leads to selective hyperactivity directed at one person, often in the form of behavioral provocations.

4. The changing environment, emotional dependence provoke the general social hyperactivity, superficiality of contacts and feelings of the child ${ }^{15}$.

In the other approach three spectra of the relationships that make up parents' love for their child are distinguished: sympathy - antipathy, respect neglect, closeness - distance. Combining these aspects of relationships allows us to describe eight types of parental love.

1. Effective love (sympathy, respect, intimacy). The formula of parental family upbringing is: "I want my baby to be happy and help it with it".

2. Alienated love (sympathy, respect, but a great distance with the child): "Look what a beautiful baby I have it's a pity I don't have much time to talk to it".

3. Effective pity (sympathy, closeness, but lack of respect). "My baby is not like everyone. Although my child is not smart enough and physically advanced but it is still my child and I love it".

4. Love by the type of condescending alienation (sympathy, disrespect, great interpersonal distance). "My child cannot be blamed for not being intelligent and physically advanced".

5. Dropping (dislike, disrespect, long interpersonal distance). "This baby makes me uncomfortable and unwilling to deal with it".

6. Contempt (dislike, disrespect, small interpersonal distance). "I am suffering infinitely because my child is so underdeveloped, stupid, stubborn, timid, unpleasant to other people".

7. Harassment (dislike, respect, intimacy). "My child is a scoundrel and I will prove it to it".

15 Лангеймер Й., Матейчек 3. Психическая депривачия в детском возрасте. Прага: Авиценум, 1984. 334 с 
8. Rejection (dislike, respect and great interpersonal distance). "I don't want to deal with this failure".

An optimal parenting position should meet three main requirements: adequacy, flexibility and predictability.

Adequacy of an adult's position is based on a real accurate assessment of the characteristics of their child, the ability to see, understand and respect their personality. A parent should not be focused solely on what he or she wants in principle to get from his or her child; knowledge and consideration of the child's capabilities and inclinations are the most important condition for successful development.

The flexibility of the parental position is seen as the willingness and ability to change the style of communication and ways of acting on the child as he or she grows up and in connection with various changes in family living conditions. "Stiffened", immature stance leads to barriers to communication, outbreaks of disobedience, rebellion and protest in response to any demands.

The predictability of the position is expressed in its orientation to the "zone of immediate development" of the child and the task of tomorrow is the leading initiative of the adult in changing the overall approach to the child taking into account the prospects of its development.

One of the main psychological and pedagogical concepts for different types of family upbringing is the notion of "parenting style" or upbringing style. As a social-psychological concept style refers to a set of ways and techniques of communication with respect to a partner. There are general, characteristic and specific communication styles. As a determinant of communication style the personality orientation is a generalized with relatively stable motivational tendency; position taken with respect to parameters of the situation of communication and to the partner. Parenting style is a generalized, characteristic, situational, non-specific way of communicating between a given parent and a given child.

Most often in the psychological and pedagogical research to determine and analyze the parental relationship two criteria are used:

1. The degree of emotional closeness, warmth of parents to the child (extreme types: love, approval, warmth - or emotional rejection, coldness);

2. The degree of control over the child's behavior (extreme types: high, with many restrictions, prohibitions; low, with minimal prohibition trends).

A more accurate description of parental attitudes and appropriate behavior requires consideration of fusion or a combination of extreme variants of the manifestation of these two factors (criteria).

We get four types of education, for example:

1. Authoritative (warm relations, high level of control).

2. Authoritarian (cold relations, high level of control).

3. Liberal (warm relations, low control).

4. Indifferent (cold relations, low level of control). 
The problem of communication of styles of education, violations of parental attitude, deviations in mental development and even health of children is investigated most actively from clinical and psychological positions. A.I. Zakharov highlighted a number of parameters of the educational process:

1. Intensity of emotional contact of parents towards children: a) hyperopic; b) guardianship; c) approval; d) rejection.

2. Control parameter: a) permissible; b) admissible; c) situational; d) restrictive.

3. Sequence - Inconsistency.

4. Affective stability - instability.

5. Anxiety - non-anxiety.

It is shown that different combinations of these educational parameters correlate with different types of neuroses in children. For example the limited, affective instability on the part of the parents leads to the development of fear in the child; over-acceptance, "permissiveness", inconsistency lead to the development of hysterical neurosis. Expressed parental limitation to children leads to neurosis of obsessive conditions.

Various researchers have described styles of family education: variants of the names of the same or very similar style of education; characterization of style by the parameters of emotional closeness, level of requirements and restrictions, degree and forms of control, features of communication; possible, most likely consequences for the mental development of children.

Thus, as V.S. Mukhina rightly points out: "in real life it is still more difficult than in any classification. Several styles of attitude towards the child can be represented in the family at one time: father, mother, grandparents can conflict with each other defending each their own style etc. In addition to the styles of relationships addressed directly to the child the parenting style of the adult family has an unconditional influence on their upbringing"16.

\section{CONCLUSIONS}

The preschool age of the child allows for the first time to call the child a person who is not yet fully developed but capable of further development and improvement. Psychological peculiarities of development of personality of preschool child are considered. The concept of family environment (childparent relations in particular) is analyzed and defined as the basis for the child's development. On this basis the psychological characteristics of children and parents in the modern family are considered. It is substantiated

\footnotetext{
${ }^{16}$ Мухина В.С. Психология дошкольника. Москва: Просвещение, 1975. 173 с.
} 
that communication of parents with the child creates for them the most favorable conditions for both physical and mental development.

On the basis of the analysis of the content of personality-oriented communication in the conditions of family interaction the necessity of development and refinement of the model of personality-oriented communication in the conditions of family interaction is substantiated. The application of this model would provide the opportunity to create the most favorable conditions for development for the development of the preschooler's personality. The basic principles are consistency, integrity, accessibility, versatility and individual approach.

The most significant and least meaningful parental orientations as well as the most and least dominant type of parental attitude to the child have been identified. When these two components are compared the relationship between them is determined.

The five components of the person-centered model of family-oriented communication are also identified: the first component is the type of family interaction; the second component is the parenting style used by parents in relation to the child; the third component is parental values; the fourth component is the emotional closeness that exists between the parent and the child and the last component is the model of communication in the parentchild dyad.

\section{SUMMARY}

An important elements of human cohabitation and relationships are psychological contacts and communication. Human being has a need for contact with similar ones all over the world but communication is a huge gift and a property of human's social life. Through communication a person learns the world and their own spirituality. He or she maintains a psychological connection with other people through mass communication and direct relations.

Communication is a multifaceted process of establishing and developing contacts between people which involves the exchange of information, certain tactics and strategies for interaction, perception and understanding of the subjects of communication with each other.

Family as the closest human environment is an important and practically indispensable chain of social identity formation.

Numerous psychological studies of both domestic and foreign authors confirm the great importance of child-parent relations in the development of communication of each individual. As G.S. Kostyuk noted "education that is reduced to external influences (orders, prohibitions, etc.) and which ignores 
internal changes in the thoughts, feelings, needs, aspirations of pupils fails. It perpetuates the negative traits of a growing personality that emerge as situational phenomena, expressing its opposition to the rough demands of adults and are further consolidated and transformed into persistent character traits".

Positive emotional atmosphere in the family and harmonious relationships between parents and the child, personal-oriented communication style contribute to the development of emotions and social feelings of the child, assimilation of their spiritual and moral values, institutions and requirements of the parents. However conflicting and tense relationships between parents and children lead to disturbances in the emotional, volitional development of children, to difficulties in social adaptation, deviations in behavior and so on.

\section{REFERENCES}

1. Вопросы психологии ребенка дошкольного возраста: Сборник статей / под ред. А.Н. Леонтьева. Москва, 1995. 144 с.

2. Выготский Л.С. Собрание сочинений: в 6-ти томах. Педагогіка. Т. 2: Москва: Психология, 1984. 397 с.

3. Лисина М.И., Силвестру А.И. Психология самопознания у дошкольников. Кишинев: “Штинца”, 1983. 63 с.

4. Психология личности и деятельности дошкольника / под ред. А.В. Запорожца, Д.Б. Эльконина. Москва: Просвещение, 1965. 98 с.

5. Актуальне проблемы воспитания и обучения дошкольников. Сборник научных трудов. Москва, Педагогика, 1985. 403 с.

6. Общение детей в детском саду и семье / под ред. Т.А. Репина, Р.Б. Стеркина и др. Москва: Педагогика, 1990. 150 с.

7. Психология семьи. Сборник статей. Москва: Вопросы психологии, 2002. С. 5-11.

8. Лисина М.И. Воспитание детей раннего возраста в семье. Киев: Знание, 1983. 48 с.

9. Дружинин В.О. Психология семьи. Москва: КСП., 1996. 368 с.

10. Титаренко В.Я. Семья и формирование личности. Москва: Мысль, $1987.342 \mathrm{c}$.

11. Эмоциональное развитие дошкольника / под ред. А.Д. Кошелевой. Москва: Просвещение, 1985. 368 с.

12. Творча спадщина Г.С. Костюка та сучасна психологія. До 100річчя від дня народження академіка Г.С. Костюка. Матеріалли III з'їзду Товариства психологів України. Київ, 2000. 311 с.

13. Смирнова Е.О. Психология ребенка. Москва: Знание, 1997. 326 с. 
14. Психология семьи. / Сборник статей. Москва: Вопросы психологии, 2002. С. 5-11.

15. Лангеймер Й., Матейчек 3. Психическая депривация в детском возрасте. Прага: Авиценум, 1984. 334 с

16. Мухина В.С. Психология дошкольника. Москва: Просвещение, 1975. $173 \mathrm{c}$.

Information about the author:

Guba N. O.,

$\mathrm{Ph} . \mathrm{D}$ in Psychological Sciences, Associate Professor, Head of the Department of Psychology, Zaporizhzhya National University 66a, Zhukovskoho str., Zaporizhzhia, 69600, Ukraine 